\title{
Histomorphological study of soft tissue tumors and review of literature of rarer types
}

\begin{abstract}
Soft tissue tumors constitute a large and heterogeneous group of neoplasms. Clinically soft tissue tumors range from benign, self limited lesions to intermediate grade to highly Aggressive. Most of soft tissue tumors are benign, while few of them are malignant in nature. It ranges from most common benign tumours to some of the rare malignant soft tissue tumors. Our aim was to study the histomorphological patterns and features with review of literature of few rare malignant soft tissue tumours the retrospective study was carried in department of pathology, from January 1, 2013 to December 31,2014 . A record was taken from total 5895Patients; among them total 794 cases of soft tissue tumors were noted. Out of which 733 cases were found to be benign $(92.8 \%)$ and 61 cases turned out to be malignant $(7.2 \%)$. The most common benign tumor was leiomyoma (52\%) followed by Haemangioma (16\%) and Lipoma $(10.1 \%)$ and common malignant tumor was Fibrosarcoma followed br Rhabdomyosarcoma. Among 794cases, 183 tumors were diagnosed in male, while 611 cases were diagnosed in females. The most common site involved was extremities.
\end{abstract}

Keywords: soft tissue, tumors, benign, malignant, leiomyoma, hemangioma, lipoma, fibrosarcoma, immunohistochemistry
Volume 4 Issue 6 - 2017

\author{
Gayatri Gogoi,' Mondita Borgohain, ${ }^{2}$ Projnan \\ Saikia, ${ }^{3}$ Brinkal Patel, ${ }^{4}$ RK Hazarika, ${ }^{5}$ RC \\ Brahma, ${ }^{6}$ Bidit Gogoi, ${ }^{7}$ Nabajyoti Saikia, ${ }^{8}$ Jolly \\ Rabha ${ }^{9}$ \\ 'Assistant Professor of Pathology, Assam Medical College, India \\ 2,3,5 Professor of Pathology, Assam Medical College, India \\ ${ }^{4}$ Graduate Trainee of Pathology, Assam Medical College, India \\ ${ }^{6}$ Associate Professor of Surgery, Assam Medical College, India \\ ${ }^{7}$ Demonstrator of Pathology, Assam Medical College, India \\ ${ }^{8}$ Associate Professor of Otolaryngology, Assam Medical College, \\ India \\ ${ }^{9}$ Assistant Professor, Pediatrics, Assam Medical College, India
}

Correspondence: Gayatri Gogoi, Assistant Professor of Pathology, Assam Medical College, Dibrugarh, Assam, India, Tel +91-9435030084, Email gayatrigogoi303@gmail.com

Received: 21 Jan, 2017| Published: June 16, 2017

\section{Introduction}

Soft tissue refers to non-epithelial tissue; it is supporting tissue which are extra skeletal excluding joints, central nervous system, skeleton, haematopoietic and lymphoid tissues. Soft tissue tumors can occur at any age. It has been noted that the histological distribution of soft tissue tumors are rather specific for a particular age group at a particular anatomical site. ${ }^{1,2}$ Both benign and malignant soft tissue tumors commonly present as a painless mass. Examples of soft tissues are Adipose tissue, Fibrous tissue, Vascular tissue, skeletal muscle tissue, Smooth muscle and Nerve sheaths. Tumors range from benign, self limited lesions to highly aggressive malignant with significant risk of metastasis and high mortality.

Soft tissue tumors have wide morphological as well as histological variation that can be detected by microscopic examination. Soft tissue tumors are uncommon and comprise about $2 \%$ or less of the cases. As benign soft tissue tumors outnumber their malignant counterpart, this tumors more or less resembles the normal tissues. There are special techniques that have been successfully applied to increase diagnostic accuracy; these include conventional special stains, electron microscopy, immunohistochemistry and cytogenetic/ molecular methods. They arise nearly everywhere in the body, the most important locations being the extremities, trunk, abdominal cavity and head $\&$ neck region. ${ }^{3}$

There is no known predisposing cause but majority of them arises sporadic. Unlike tumors like carcinoma that usually arises from recognized precursor lesions; the origin of sarcomas is unknown. It has been postulated that the tumors arises from pluripotent mesenchymal stem cells, which acquires somatic driver mutation in ongogenes and tumor suppressor genes. Reports have linked specific genetic, immunodeficiency, viral infection and environmental factors with the development of some STS. Environmental factors (e.g., radiation, herbicides) have been associated with the development of specific types of sarcomas..$^{48}$ Some sarcomas have a higher predisposition to occur in the setting of familial cancer syndromes (e.g., retinoblastoma syndrome, Li-Fraumeni syndrome, hereditary leiomyomatosis and renal cell carcinoma). ${ }^{9-12}$ These observations suggest that both environmental and genetic factors are important in the development of these tumors.

\section{Aims and objectives}

i. To study histomorphology and characteristic patterns of different soft tissue tumours.

ii. 2. To describe the difficulties and application of immunohistology in confirmation.

iii. Review of literature of few rare malignant tumours.

\section{Material and methods}

It was a descriptive study of Soft tissues tumors over a period of 2years (January 2013- to December 2014) conducted in the Department of Pathology, in Histopathology and immunohistochemistry Laboratory of Assam Medical Hospital and College, Dibrugarh. Total records of 5895patients were verified in documentation section. Relevant formalin fixed paraffin embedded blocks in archive of Pathology were retrieved. The Standard operating procedure to receive samples in histopathological laboratory from different departments and operation theatures was with proper identification, labeling and origin. The format contains basic informations such as Name, Age, Sex, Hospital No, Specimen No, Date of specimen collected, Location of tumor and Clinical presentation and other investigations findings. The Histopathology tissue processing protocol involved fixation in 
$10 \%$ buffered formalin ( $\mathrm{PH}$ 7.2-7.4) with volume 10times more of tissue size for 12-36hours according to type of specimen. Additionally bony tissues were decalcified to remove calcium salt. The grossing were carried out on same day or next day with special emphasis to location, size in 3 dimensions of specimen, Morphological features of tissue and tumor, size of tumor and other representative areas. At least 4 Sections from tumour and one from each margins in general were taken in appropriate size to fit the cassettes and were labeled, which were kept in $10 \%$ formalin as mentioned The sections were processed under standardized condition for dehydration using acetone for 2 hours, changing acetone every 30 minutes followed by process of clearing using Benzene for 30minutes and later paraffin embedding and block making.

Diagnosis of soft tissue tumour blocks . The slides were reviewed to record histopathological details in the study Performa. An additional slide of a thickness of tissue 4-5microns were made with help of Rotary microtome and prepared for routine stain with Haematoxylin and Eosin to examine under light microscope for histopathological features followed by ascertaining the type of soft tissue tumour. Where ever diagnosis was difficult or a differential diagnosis was made, ancillary study by immunohistochemistry was done to confirm the type. The primary antibodies and secondary detection system containing horse radish peroxides belonged to FDA approved company were used. The markers used in IHC were myogenin, EMA CK, CD99, chromogranin A CD31, S100, CD117, Desmin, Calretinin, Smooth muscle antigen and Vimentin. Approximately $3-4 \mathrm{~mm}$ tissue sections were taken in 3-Aminopropyl triethoxysilane coated slide along with control slide. The step was followed by deparaffinization in descending grades of alcohol, which was followed by antigen retrieval with TRIS buffer. Dedicated antigen retrieval (EZ-Retriever System v.3) was used for optimum retrieval of epitopes in a standardized laboratory condition. The non specific sites were blocked by peroxidase and power block inside a humidity chamber. Primary antibodies were incubated for duration of one hour. Finally secondary antibody, Super Enhancer Polymer-HRP and DAB chromogen was used in multiple steps. It was then counterstained with iron free hematoxylin.

The histopathological examination of all $\mathrm{H}$ and $\mathrm{E}$ stained slides were done as following:

i. Identification of pattern of soft tissue

ii. Histological type of tumor (Benign or Malignant).

iii. Grading of tumor in case of malignancy.

iv. IHC done in selected cases of undifferentiated malignant tumors.

\section{Results}

The soft tissue tumors were classified based on WHO classification". The relevant data's were collected and recorded such as Age, Sex, Location of tumor and a final diagnosis were given with gross and microscopic characteristics. A total of 5895 cases were collected, out of which total 794 cases were noted to be a soft tissue tumors. In Table 1, Among 794 positive sample, 61 cases found to be malignant and rest cases was benign in nature. According to Table 2, the histological type, the most common type was found to be from Muscular tissues i.e 442 cases $(55.7 \%)$, followed by vascular tissues i.e. 157 cases $(19.8 \%)$ and Lipomatous tissues i.e 83cases(10.4\%).Incidence of Fibroblastic/ My fibroblastic and Peripheral nerve sheath types were found to be almost equal. tumors have been mentioned. Soft tissue tumors were commonly seen in female gender (79.0\%). Lipoma and hemangioma are most commonly seen in both genders. In the Table 3, some common types of benign and malignant soft tissue In Female most common benign tumor was leiomyoma followed by hemangioma, lipoma, fibroma, Nevus, schwanomma and neurofibroma while common malignant tumors was Rhabdomyosarcoma followed by synovial sarcoma.

Table I Tumor according to the classification

\begin{tabular}{lll}
\hline Soft tissue tumor & Number of cases & Percentage \\
\hline Benign & 733 & $92.8 \%$ \\
Malignant & 61 & $7.60 \%$ \\
Total & 794 & $100 \%$ \\
\hline
\end{tabular}

Table - I : Tumor according to the classification

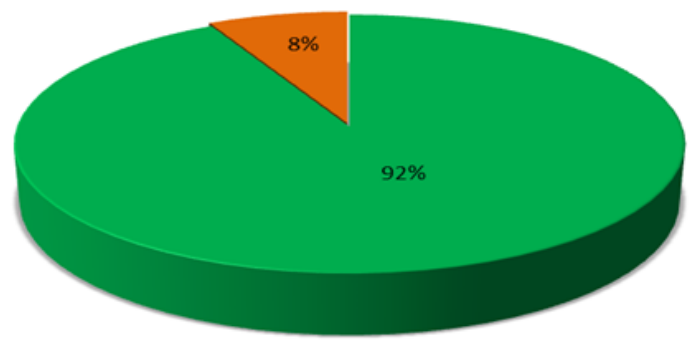


Table 2 Tumor according to histological type

\begin{tabular}{lll}
\hline Histological type & Number of cases & Percentage \\
\hline Lipomatous tissues & 83 & $10.40 \%$ \\
Fibroblastic/Myofibroblastic tissues & 55 & $6.90 \%$ \\
Muscular tissues & 442 & $55.70 \%$ \\
Peripheral nerve sheath & 53 & $6.7 \%$ \\
Vascular tissues & 157 & $19.80 \%$ \\
Miscellaneous & 4 & $0.50 \%$ \\
Total & 794 & 100 \\
\hline
\end{tabular}

Table II: Tumor according to Histological Type

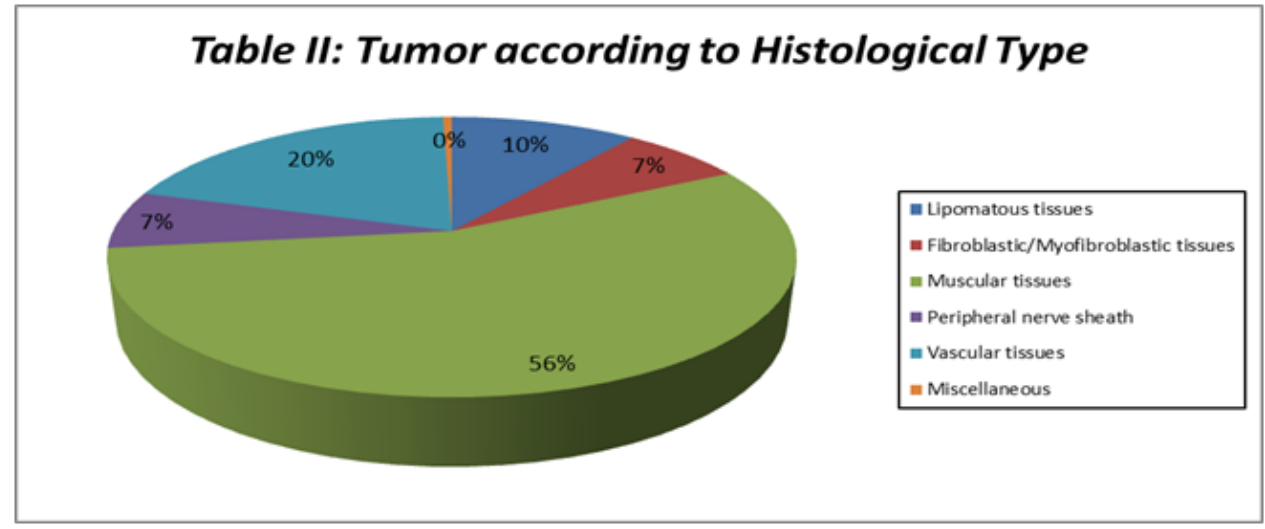

Table 3 Tumor according to gender distribution

\begin{tabular}{|c|c|c|}
\hline Type of tumor & Female & Male \\
\hline Leiomyoma & 408 & 2 \\
\hline Fibroma & 25 & 19 \\
\hline Lipoma & 42 & 38 \\
\hline Hemangioma & 65 & 61 \\
\hline Nevus & II & 7 \\
\hline Schwanomma & 11 & 6 \\
\hline Neurofibroma & 3 & I \\
\hline Giant cell tumor & 2 & 2 \\
\hline Glomus tumor & 3 & 0 \\
\hline Synovial sarcoma & 3 & 0 \\
\hline Liposarcoma & I & 2 \\
\hline Fibrosarcoma & 2 & 5 \\
\hline Malignant fibrous histiocytoma & 0 & 4 \\
\hline Rhabdomyosarcoma & 3 & 3 \\
\hline Lieomyosarcoma & 0 & 1 \\
\hline Dermatofibrosarcoma protuberance & I & 0 \\
\hline Ganglioneuroblastoma & 0 & 2 \\
\hline Malignant haemangioendothelioma & I & I \\
\hline Percentage & 0.79 & 0.21 \\
\hline
\end{tabular}




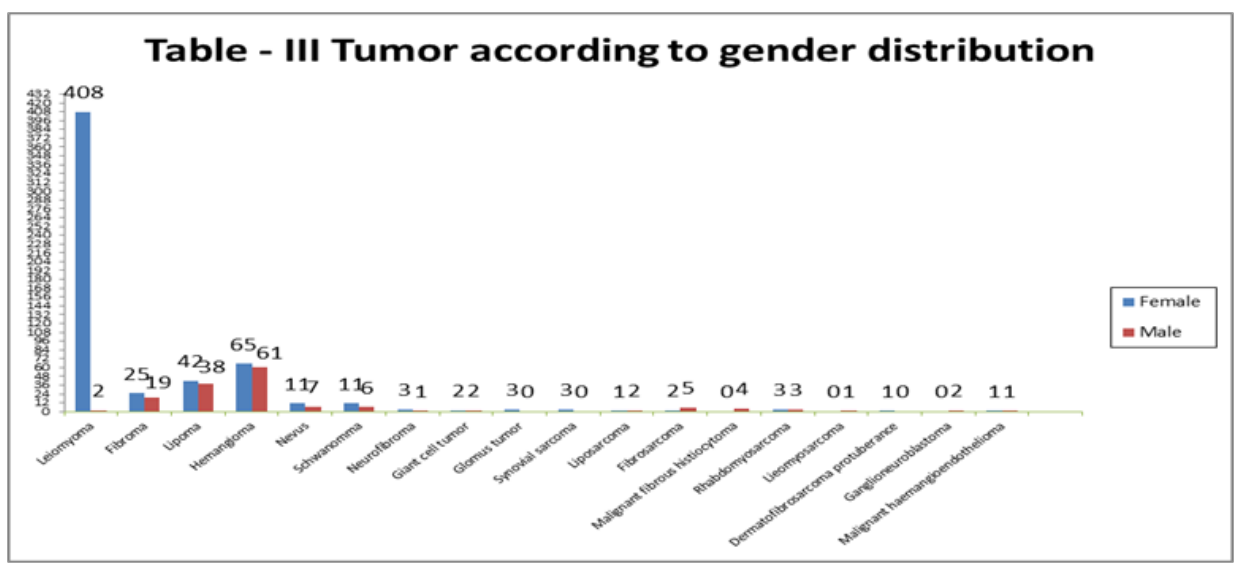

In Male common benign tumor was Haemangioma followed by lipoma, Fibroma, Nevus and schwannoma while common malignant tumor was Fibrosarcoma followed by malignant fibrous histiocytoma, Rhabdomyosarcoma and Liposarcoma. In Table 4, as per the locations, Benign soft tissue tumors are commonly located in pelvis and Retroperitoneal sites (58.8\%), among which uterus was the most common site, followed in decending order by Head and neck region (22.5\%), Upper limb, Lower limb, Chest and Abdomen and Back region. Common site for Schwanomma and Neurofibroma, Giant cell tumor, Glomus tumor was Head and Neck and Upper limb respectively.
Among Malignant tumors Liposarcoma was commonly seen in Pelvis and Retro peritoneum followed by Fibrosarcoma in Chest and Abdomen region, malignant fibrous histiocytoma equally on Head and neck, upper limb, Chest and Abdomen and Back region. Rhabdomyosarcoma common site was Head and neck region, Ganglioneuroblastoma equally on Head and neck, Chest and Abdomen region. Synovial sarcoma equally on Head and Neck, Lower limb, Chest and Abdomen region and Malignant Hemangioendothelioma on Chest and Abdomen and Lower limb respectively. IHC was required mostly in diagnosis of malignant soft tissue tumours as adjunt to histology. The Common Markers used to differentiate subcategorisation of Soft tissue tumors are shown in Table 5.

Table 4 Tumors according to locations

\begin{tabular}{|c|c|c|c|c|c|c|c|}
\hline Type of tumors & $\begin{array}{l}\text { Head and } \\
\text { neck }\end{array}$ & $\begin{array}{l}\text { Upper } \\
\text { limb }\end{array}$ & $\begin{array}{l}\text { Lower } \\
\text { limb }\end{array}$ & $\begin{array}{l}\text { Chest and } \\
\text { abdomen }\end{array}$ & $\begin{array}{l}\text { Pelvis and } \\
\text { retroperitoneum }\end{array}$ & Back & Total \\
\hline Leiomyoma & & 01 & & & 408 & 01 & 410 \\
\hline Fibroma & 18 & 12 & 05 & 03 & 05 & 01 & 44 \\
\hline Lipoma & 20 & 24 & 11 & 07 & 06 & 12 & 80 \\
\hline Hemangioma & 101 & 15 & 07 & 01 & 01 & 01 & 126 \\
\hline Nevus & 14 & - & - & 02 & 01 & 01 & 18 \\
\hline Schwanomma & 05 & 01 & 01 & 04 & 04 & 02 & 17 \\
\hline Neurofibroma & - & 02 & 01 & - & 01 & - & 04 \\
\hline Giant cell tumor & - & 03 & 01 & - & - & - & 04 \\
\hline Glomus tumor & 01 & 02 & - & - & - & - & 03 \\
\hline Synovial sarcoma & 01 & - & 01 & 01 & - & - & 03 \\
\hline Liposarcoma & - & - & 01 & - & 02 & - & 03 \\
\hline Fibrosarcoma & - & - & 01 & 03 & 02 & 01 & 07 \\
\hline $\begin{array}{l}\text { Malignant fibrous } \\
\text { histiocytoma }\end{array}$ & 01 & 01 & - & 1 & - & 01 & 4 \\
\hline Rhabdomyosarcoma & 3 & - & 2 & - & 1 & - & 6 \\
\hline Leimyosarcoma & & & & & 1 & & 1 \\
\hline $\begin{array}{l}\text { Dermatofibrosarcoma } \\
\text { protuberance }\end{array}$ & - & - & 01 & - & - & - & 01 \\
\hline Ganglioneuroblastoma & 01 & - & - & 01 & - & - & 02 \\
\hline $\begin{array}{l}\text { Malignant } \\
\text { hemangioendothelioma }\end{array}$ & - & - & 1 & 01 & - & - & 01 \\
\hline Percentage & $22.50 \%$ & $8.30 \%$ & $4.40 \%$ & $3.30 \%$ & $58.80 \%$ & $2.70 \%$ & $100.00 \%$ \\
\hline
\end{tabular}




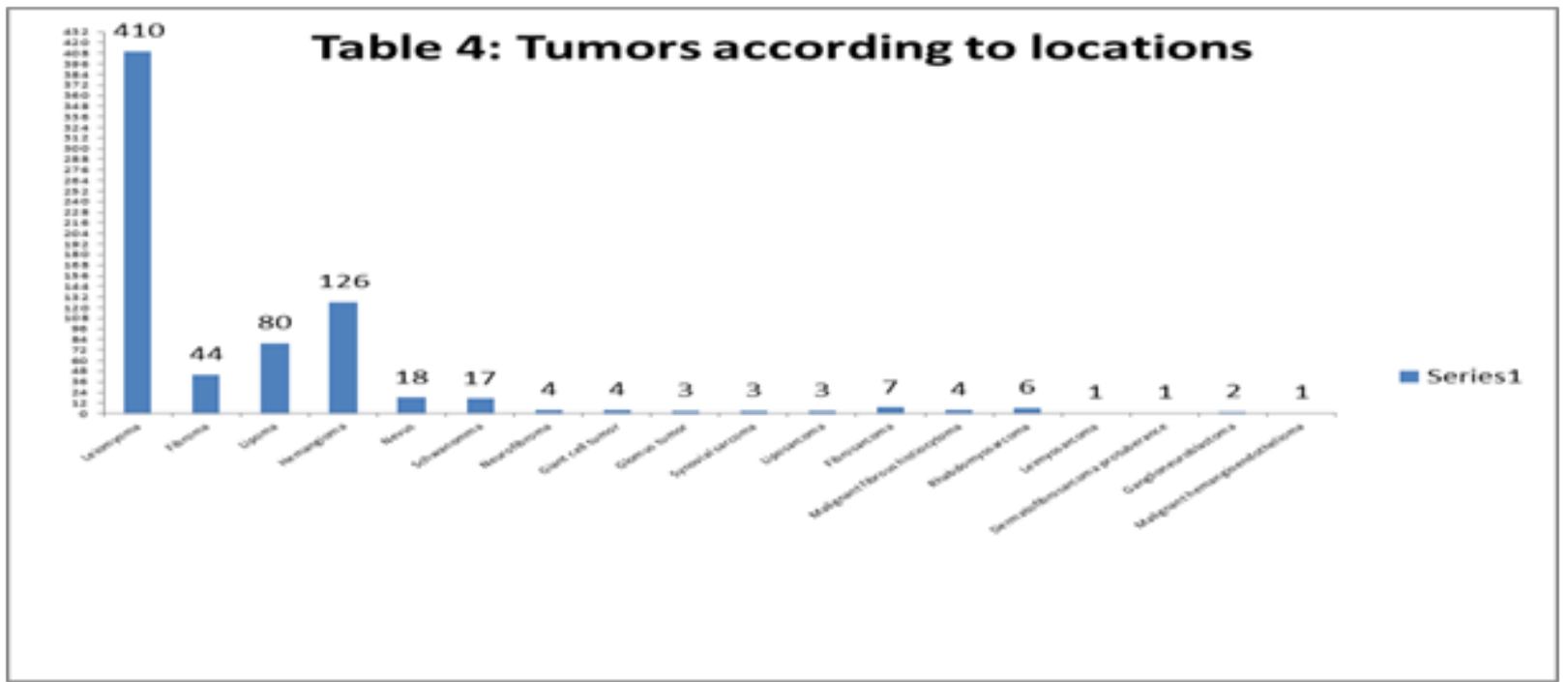

Table 5 Immunohistochemistry in malignant soft tissue tumors

\begin{tabular}{ll}
\hline Tumors & Marker positivity \\
\hline Leiomyosarcoma & SMA+, Desmin+, Myogenin- \\
Liposarcoma & SI00+,Vimentin+, Desmin-, Myogenin- \\
Fibrosarcoma & Vimentin+, Desmin-, Myogenin- \\
Rhabdomyosarcoma & Desmin+, Myogenin+, SMA- \\
Synovial Sarcoma & EMA+, Cytokeratin+,Vimentin+,BCL2+ \\
Malignant Fibrous Histiocytoma & Vimentin+, Desmin-, EMA- \\
Dermatofibrosarcoma protuberance & CD34+, others - \\
Malignant hemangioendothelioma & CD34+, CD31+, Desmin - \\
\hline
\end{tabular}

\section{Discussion}

Enzinger F.M. \& W.W. Weiss, Myhre Jenson et al. ${ }^{13}$ reported an incidence of soft tissue tumors as $0.8-1 \%, 0.8 \%$ and $<2 \%$ respectively. This was the first study undertaken in this tertiary care institute on soft tissue tumour to describe patterns of soft tissue tumours. However the study was restricted to documentation the information about incidence, sex and site distribution of soft tissue tumors and confirming the morphological diagnosis with immunohistochemistry. Soft tissue tumors vary from most common benign Leiomyoma, Haemangioma, and Lipoma to some rare malignant ones. Thus incidence of benign tumor 12times more common than malignant in case of soft tissue tumors. We also encountered very rare types of malignant soft tissue tumour such as malignant hemangioendothelioma, granular cell tumour of tongue, Desmoblastic rhabdomyosarcoma etc.

Soft tissue tumors are diagnosed in Excisional biopsy of tumor mass and it is most appropriate method of diagnosis of Soft tissue tumors .The histological diagnosis and grading is mandatory as it has therapeutic and prognostic relevance. ${ }^{14}$ Among benign tumors Leiomyoma was most commonly seen in females and are very common in uterus followed by Hemangioma and lipoma, while in Male most common was Haemangioma followed by lipoma. Haemangioma are localized lesions confined to head and neck region while lipoma is usually painless soft mass common in neck, shoulder, lower limb and upper limb. Cases are more seen among females than males.

IHC was required mostly in diagnosis of malignant soft tissue tumours as adjunt to histology. Myogenin and Myo D1 were used for identifying origin of skeletal muscle origin. Similarly specific markers such CD31 was applied for blood vessel origin, S100 for shwannonian tumours and Liposarcoma, EMA for synovial sarcoma and MPNST and Vimentin for fibro sarcoma. Benign soft tissue tumors were more common than malignant tumors in our study, similar to the studies done by Angerwall et al. ${ }^{15}$ Enzinger, F.M.S.W. Weiss reported a benign to malignant ratio as 5:1 and 18.5 to $100: 1$ respectively. ${ }^{14-16}$ In present study benign to malignant ratio is $12: 1$

The general site distribution of benign soft tissue tumors site incidence as reported is $10 \%$ in head and neck region, $30 \%$ in Trunk, $20 \%$ in upper extremities, $40 \%$ in lower extremities. According to Natrajanm et al. ${ }^{17}$ \& Costa $\mathrm{J}$ et al. ${ }^{18}$ the site distribution of benign soft tissue tumors was $4-9 \%$ in head \& neck, $32 \%$ in trunk and $60-64 \%$ in extremities. ${ }^{17}$ In the present study the site distribution of soft tissue 
tumors was found to be $58.8 \%$ in pelvic and retroperitoneum, $22.5 \%$ in head \& neck, $8.3 \%$ upper extremities, $4.4 \%$ lower extremities, $3.3 \%$ in chest and abdomen and $2.7 \%$ in back region. The rise in incidence of soft tissue tumors in Pelvis and Retroperitoneal region was due to the higher incidence of Leiomyoma followed by haemangiomas in Head and Neck region.

In our study benign soft tissue tumors were found more commonly in Females than males, observation made by Dev \& Cotran reported an incidence of $58 \%$ in males, Costa $\mathrm{j}$ et al. ${ }^{18}$ reported an incidence of 55$60 \%$ in males..$^{18,19}$ Mythre Jenson $\mathrm{O}$ et al. ${ }^{13}$ Torjani et al. ${ }^{20}$ Tsuji Moto $\mathrm{M}$ et al. ${ }^{20}$ reported an incidence of $55-60 \%$ in males which in present study female sex incidence was found to be common $81 \%,{ }^{19,20}$ while male sex incidence was found to be $19 \%$. Haemangiomas were the second most common benign tumors and the common site was head and neck. Similar observations were made by Dev. Sex incidence of peripheral nerve tumors was observed to be more common in females in our study while studies done by Evans Enzinger FM Oberman \& Sullenger 1967 show almost equal incidence..$^{21,22}$

Glomus tumors occur in adults of all ages and sometimes in children, as per the study of Kohout \& Stout. ${ }^{23}$ In the present study we had 2 cases of glomus tumor constituting less than $1 \%$ of benign soft tissue tumors. In a review of 20 cases of Riversos \& Pack 1950,15 cases $(75 \%)$ occurred in the upper extremity, out of which 7 cases $(35 \%)$ were noticed subungually, 8 cases $(40 \%)$ occurred in lower extremity and 2 cases $(10 \%)$ in trunk \& 1 case $(1 \%)$ in head \& neck region. The site distribution in our study revealed that both the cases occurred in upper extremity (Figure1). Present study showed 11 cases of lymphangiomas found commonly in females. All of the cases occurred in head $\&$ neck region. This was similar to studies done by Willis 1967 and Watson \& McCarthy 1940.

Weiss \& Mentzel in their study of 46 and 24 cases reported hemangioendothelioma in deep soft tissues. In our study we had only 2 cases seen in Chest and Abdomen and lower limb region. Immunohistochemistry showed positivity for CD34 in our study. Fibrosarcoma comprise $5-10 \%$ of sarcomas according to Markhede G et al. ${ }^{24}$ In the study 7 cases of fibro sarcomas were noted constituted an incidence of $24.1 \%$ of all soft tissue sarcomas. In a review of 695 cases at AFIP 1970-79, 10\% in head and neck, 17\% trunk, 28\% in upper extremities \& 45\% in lower extremities. Bizer LS 1971 noted a site distribution of $7.8 \%$ in head and neck, $51 \%$ in trunk, $17 \%$ in upper extremities \& $23 \%$ in lower extremities. ${ }^{25}$ Hidayat $\mathrm{AA}^{26,27}$ and Enzinger FM \& SW Weiss reported site distribution of $85-90 \%$ in extremities in which $50-60 \%$ was in lower extremity, $10-15 \%$ occurred in head and neck and trunk region. In our study most common site was Chest and Abdomen (trunk) followed by Pelvis and Retroperitoneal region. The incidence of liposarcoma reported by Costa $\mathrm{J}$ et al. ${ }^{18}$ was $10-25 \%$ among soft tissue sarcoma. In the present study 3 cases were seen with an incidence $10.3 \%$ with male preponderance. Similar findings were found in studies done by AFIP, Reszel and Spittle Stout AP \& Lattles $\mathrm{R}$ and Kindblomtt et al. ${ }^{15}$ reported a male preponderance. In present study all the cases showed positivity for S-100 (Figure 2).

Synovial sarcoma constitutes about $6-15 \%$ of all sarcomas as per Coasta $\mathrm{J}$ et al. ${ }^{18}$ In the present study the incidence was $10.3 \%$ of all soft tissue sarcomas. Studies by Mackenzie DH 1977, revealed M: F ratio to be $1.4: 1$ to $2: 1$, Cagle LA et al. ${ }^{27}$ reported roughly equal incidence in both sexes. ${ }^{27,28}$ In the present study 3 cases were noted, all seen in Female. In a review of 141 cases on the records of surgical pathology division of Columbia university revealed 61 cases $(43.3 \%)$ in lower extremities including 9cases in foot, 44 cases $(31.2 \%)$ in trunk and 13 cases $(9.2 \%)$ in head\& neck region. Review by Leslie A et al. ${ }^{28}$ of 63 cases, found lower extremities to be the common sites. ${ }^{29}$ In the present study there were 3cases which occurred in Lower extremity, Head and Neck and Chest and Abdomen region equally. In immunohistochemical study of 100 synovial sarcomas by Guillou et al. focal positivity for EMA and cytokeratin was found in $97 \%$ and $69 \%$ of cases. In present study, positivity for EMA and cytokeratin was seen.

In the study done by Anders Rydholm, out of 278 soft tissue sarcomas, $22 \%$ were malignant fibrous histiocytoma. Hashimoto $\mathrm{H}$ et al. ${ }^{30}$ Costa $j$ et al. ${ }^{18}$ \& Lawrence et al. ${ }^{17}$ stated that $12-33 \%$ of soft tissue sarcomas were MFH. ${ }^{31}$ Present study shows an incidence of $13.8 \%$ of MFH out of all soft tissue sarcomas. Rooser B reported a sex incidence of M:F1.1:1. Obrein and Stout De Rosai \& Lattes reported major site as in lower extremity \& followed by chest wall, upper extremity and retroperitoneum. In the present study 4 cases were noted with Male preponderence, with equal distribution on Head and Neck, Upper extremities, chest and Abdomen and Back region. In present study, out of four cases, one case of Malignant Fibrous Histiocytoma Giant cell type, a rare type was noted in 48 years old male patient. The Location of tumor was on abdominal wall. Immunohistochemistry was done which shows positivity for Vimentin and negative for Desmin and Cytokeratin (Figure 3-7). The existence of neoplasms bearing light microscopic features of giant cell tumor of bone (osteoclastoma) has been the focus of much attention and controversy in the literature. Such tumors were first described as a distinct pathologic entity by Rosai $^{32}$ who reported two cases of this condition. Since then, ten additional cases have been added to the literature. ${ }^{33-40}$

Jeffrey reported another case in which ultrastructural examination failed to reveal epithelial features. The findings in their case, which in the opinion of the authors did not preclude an epithelial origin, more closely resembled those of giant cell tumor of bone. More recently, Manci et al. ${ }^{41}$ have described the ultrastructural features of an OGTP in which desmosomes and microvillus could not be identified, leading them to suggest that their case may be more closely related to extra skeletal osteoclastomas or to the giant cell type of malignant fibrous histiocytoma. Dimitris P, Agamandis in 1986 reported an incidence of Rhabdomyosarcoma as $19 \%$ of all soft tissue sarcoma. In the present study, we encountered 6cases of Rhabdomyosarcomas constituting an incidence of $20.7 \%$ of all soft tissue sarcomas. Out of 6 cases one case was of embryonal rhabdomyosarcoma, which was positive for desmin, myogenin.

In present study out of 6cases, one case of Sclerosing Rhabdomyosarcoma was noted involving Head and Neck region (tongue), in 50years old male patient. Immunohistochemistry was done which shows strong positivity for Vimentin, weakly positivity for Desmin and 40\% tumor cells positivity for Myogenin (Figure 8, Figure 9, Figure $10 \&$ Figure 11). SRMS is an unusual variant of RMS that was first described in 2000 by Mentzel et al. ${ }^{42}$ They described three cases of RMS in adult patients, characterized by prominent hyaline sclerosis and a pseudo vascular growth pattern, and termed sclerosing, pseudo vascular rhabdomyosarcoma. In 2002, Folpe et $a l .^{43}$ also described four cases of an unusual hyalinizing, matrix-rich variant of RMS. They named it as sclerosing rhabdomyosarcoma. ${ }^{43}$ However, so far, there was still less than 40reported cases (the present case is not included) in English literatures ${ }^{44-48}$ According to Julie. among the 39reported cases, SRMS can arise in a broad age ranged from 0.3 to 79 years with an average age at 27 . The most commonly 
involved sites (including the present case) are the extremities (19/40) and head and neck (16/40). ${ }^{48}$ Histological, SRMS has a characteristic constellation of features and is characterized by hyalinized, eosinophilic to basophilic matrix. ${ }^{49}$ Immunohistochemically, SRMS is usually strongly positive for Vimentin, Desmin and MyoD1, and weakly, focally positive for Moygenin suggesting its skeletal muscle differentiation, but negative for CK, S-100, CD34, and CD31. ${ }^{42,43,46,47}$

Gutierrez $\mathrm{G}$ et $\mathrm{al}^{26}$ reported incidence of $1.1 \%$ of Dermatofibrosarcoma protruberance of all the soft tissue sarcomas and $0.06 \%$ of all malignant tumors. ${ }^{50}$ In the present study they constituted about $3.4 \%$ of all the soft tissue sarcomas. Gutierrez $\mathrm{G}$ et al. ${ }^{26}$ reported a male predominance accounting to $36 \%$. Males are more frequently affected as reported by Enzinger FM \& Weiss SW. In the present study a Female patient was involved. In a review of 853 cases at AFIP 196079 the site distribution was noted to be $14.5 \%$ in head and neck, $47.4 \%$ in trunk, $18.2 \%$ in upper extremities, and $19.9 \%$ in lower extremities. In the present study 1 case was noted in the lower extremity, which shows CD34 positivity. Only 1 case of Leiomyosarcomas was encountered in our study, constituting an incidence $3.4 \%$ of soft tissue sarcoma. The Location of tumor was Paratesticular region, a rare site in 71years old male patient. Immunohistochemistry shows strong positivity for SMA and Desmin, Moderately positivity for EMA and Vimentin and negative for S100 and Myogenin (Figures 12-14).

Leiomyosarcomas of the genitourinary tract account for $<5 \%$ of all sarcomas and $<2 \%$ of all urological tumors. Approximately 100 paratesticular leiomyosarcomas have been reported in the literature. Leiomyosarcoma is a malignant soft tissue tumor that can arise from any tissue containing smooth muscle. However, leiomyosarcoma arising in paratesticular tissue is extremely rare and approximately only $10 \%$ of all paratesticular sarcomas are leiomyosarcomas. ${ }^{51}$ Paratesticular leiomyosarcoma originates from the spermatic cord, the scrotum, or the epididymis. The most common type is the spermatic cord type, which arises from undifferentiated mesenchymal cells of the cremasteric muscle and the vas deferens. The epididymal and scrotal types are less frequent and they originate from the smooth muscle surrounding the basement membrane of the epididymal canal and dartos layer, respectively. ${ }^{52}$ On immunohistochemical staining, expression of smooth muscle actin, muscle-specific actin and desmin is observed in most leiomyosarcomas, while expression of CD117, myogenin, Ki-67, S-100 protein and cytokeratin has also been reported in some cases. ${ }^{53}$

In present study 1 case of granular cell tumor (mixed Schwann cells and squamous cell origin) was found and was included in miscellaneous category. The tumor was found in Head and Neck region (Mandible), in 35years old Male patient. Immunohistochemistry shows positivity for S-100 and Cytokeratin and negative for Myogenin (Figures 1519). GCTs are rare benign neoplasms, they may involve any organ of the body, about $50 \%$ of the tumors are found in the head and neck area. ${ }^{54,55}$ Granular cell tumors are more frequently found in adults, with rare occurrences in the pediatric population. Usually include benign tumors as they account for $98 \%$ of the cases. ${ }^{56} \mathrm{GCT}$ s are almost always benign, but malignant manifestations are found in $1-2 \%$ of the patients. They are preferentially located in the skin and subcutaneous region. They involve the regional lymph nodes, although distal metastasis is uncommon. Malignancy is suspected from a series of factors. ${ }^{57}$ In immunohistochemistry granular cell tumors are positive for protein S-100 and neuron-specific enolase.

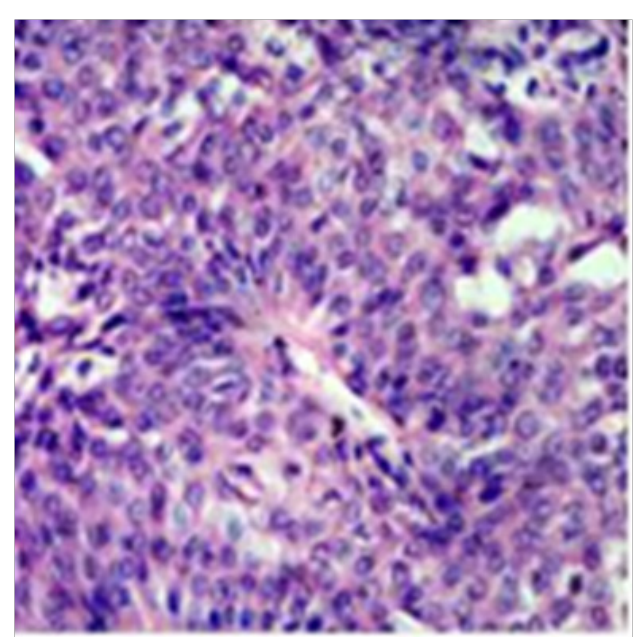

Figure I GLOMUS Tumor.

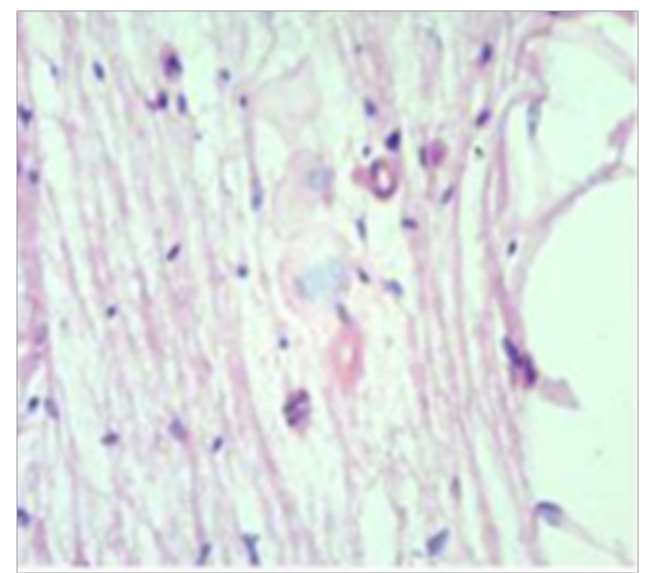

Figure 2 LIPOSARCOMA.

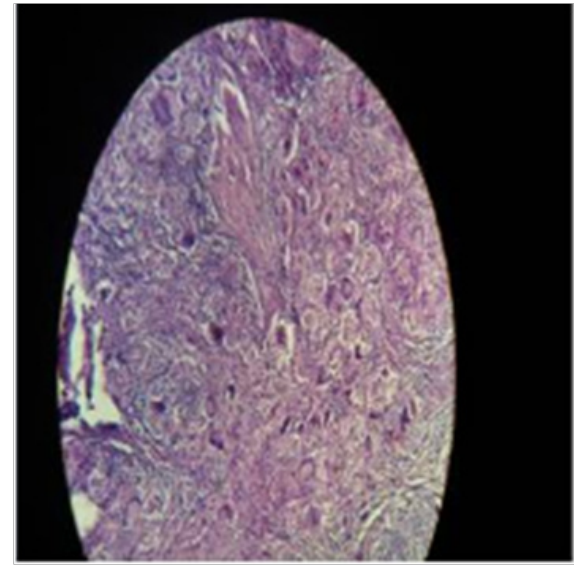

Figure 3 MALIGNANT fibrous histocytoma gaint cell type. 


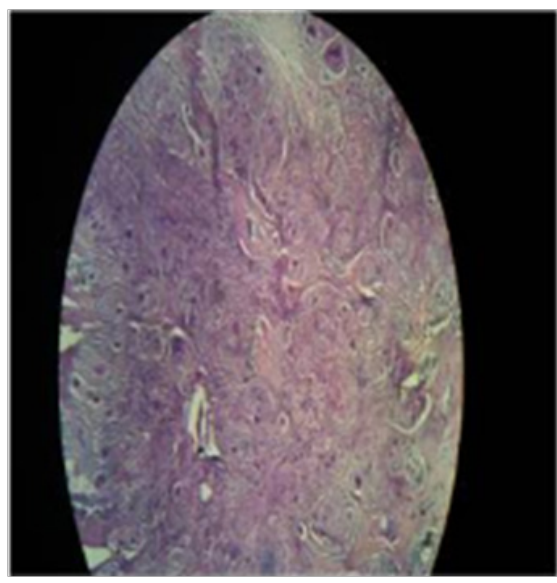

Figure 4 MALIGNANT fibrous histocytoma gaint cell type.

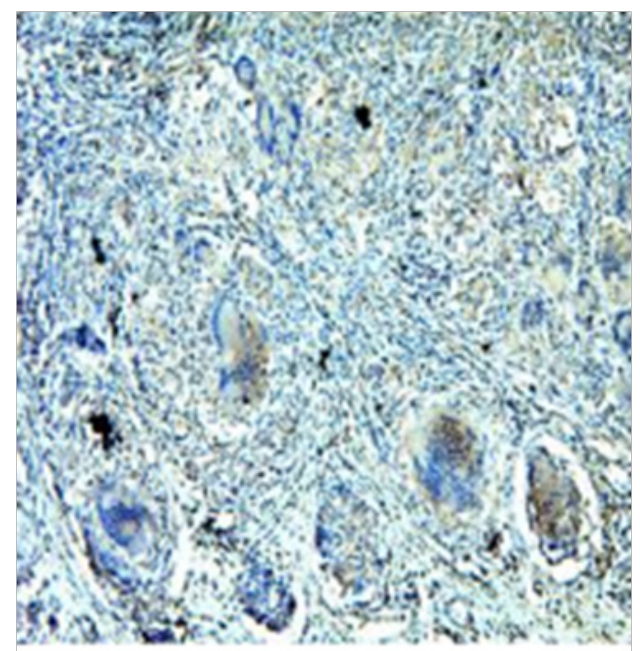

Figure 5 showing VIMENTIN positivity.

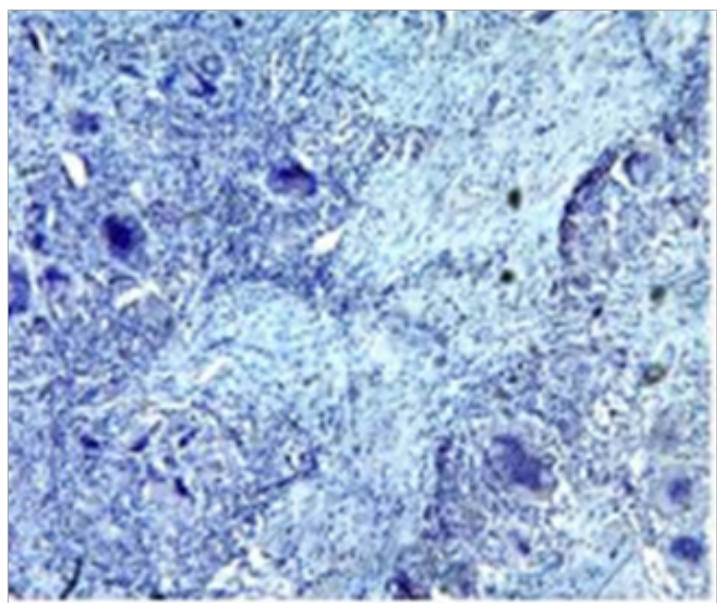

Figure 6 Showing DESMIN positivity.

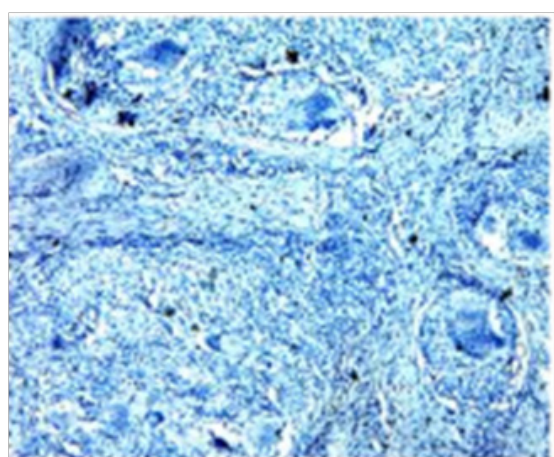

Figure 7 CYTOKERATIN negativity

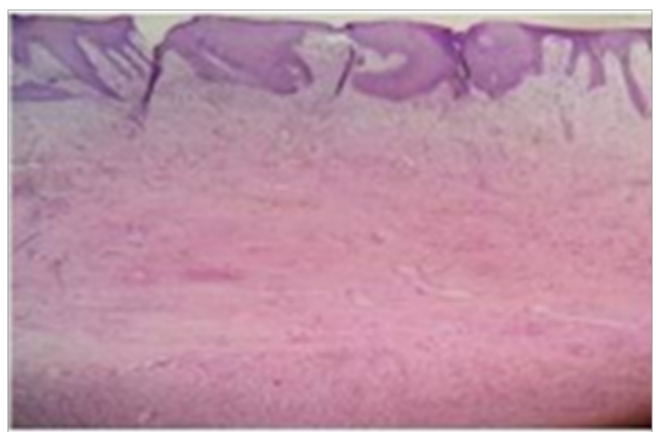

Figure 8 SCLEROSING Rahbdomyosarooma.

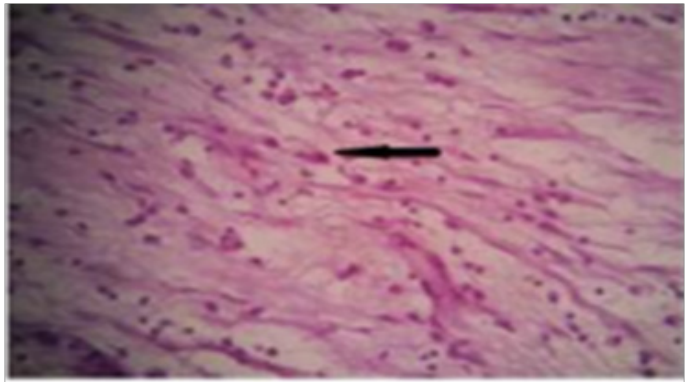

FIGURE 9 SCLEROSING rahbdomyosarooma.

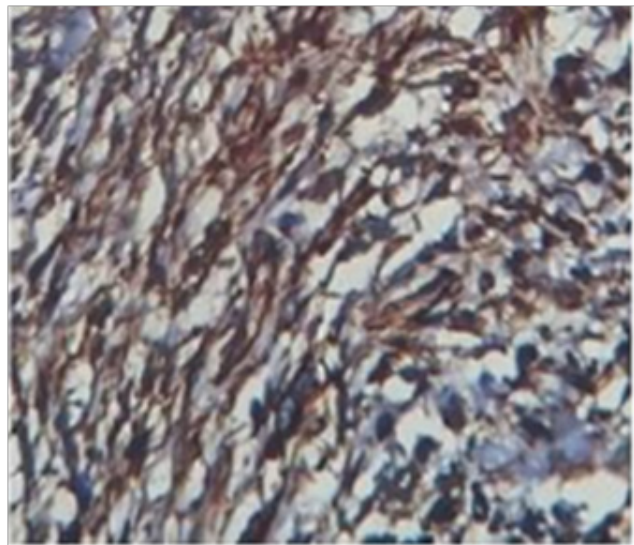

Figure 10 Showing VIMENTIN positivity. 


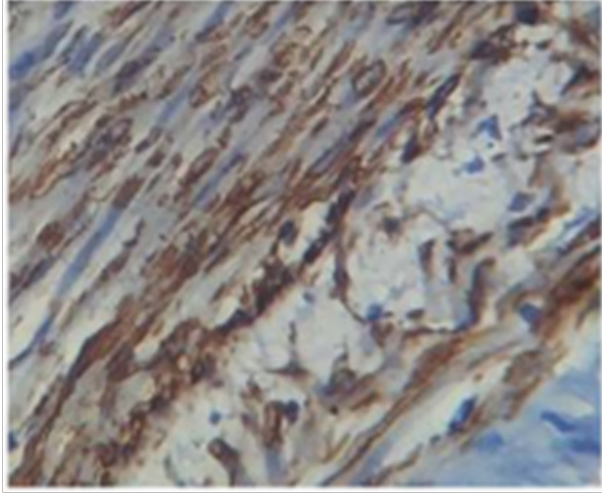

Figure I I MYOGENIN positivity in $40 \%$ of tumor cells.

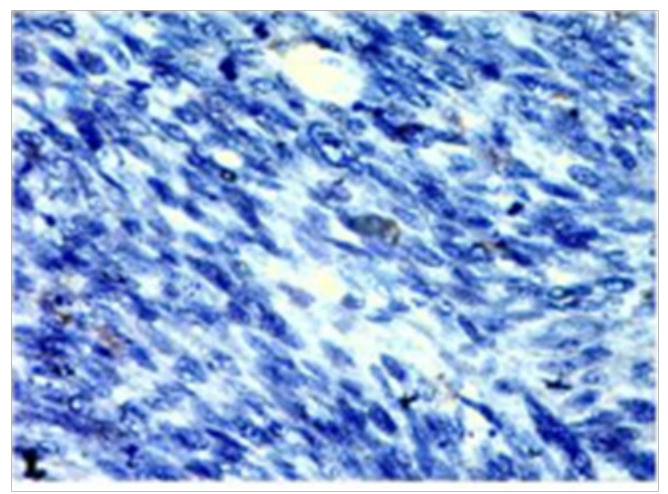

Figure 12 LEIOMYOSARCOMA showing SM actin.

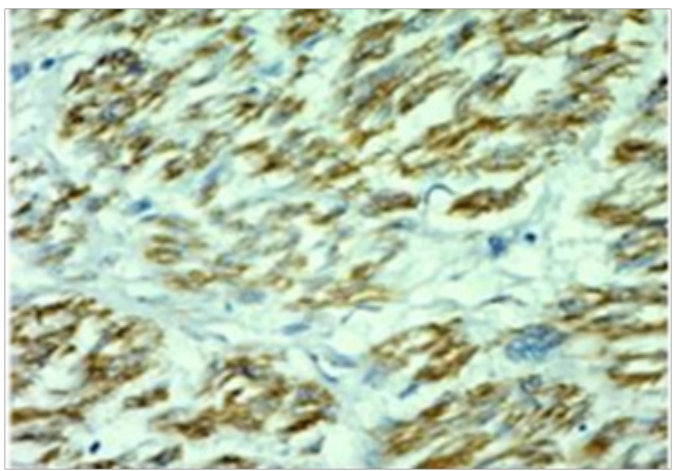

Figure 13 Showing DESMIN positivity.

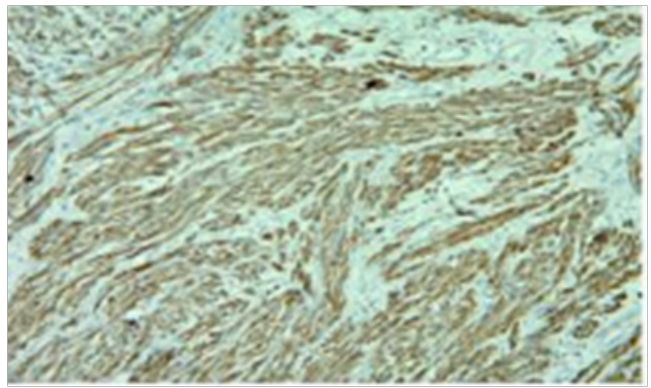

Figure I 4 Showing DESMIN positivity.

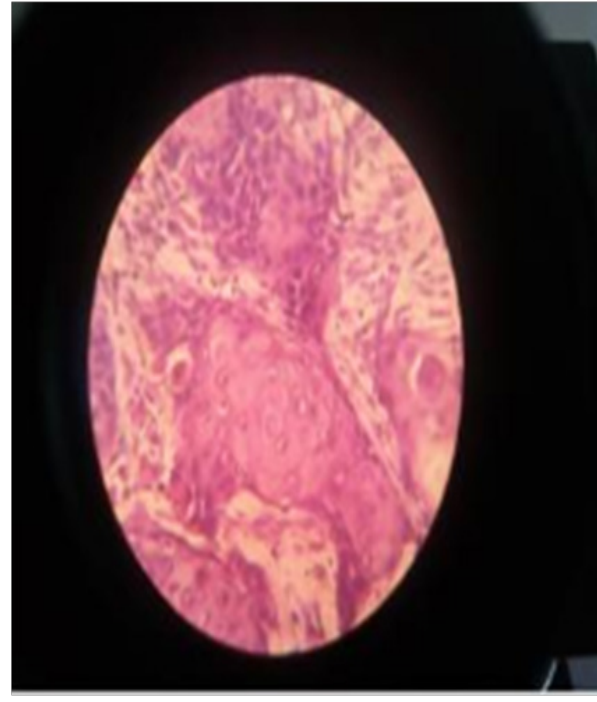

Figure 15 Granular cell tumor.

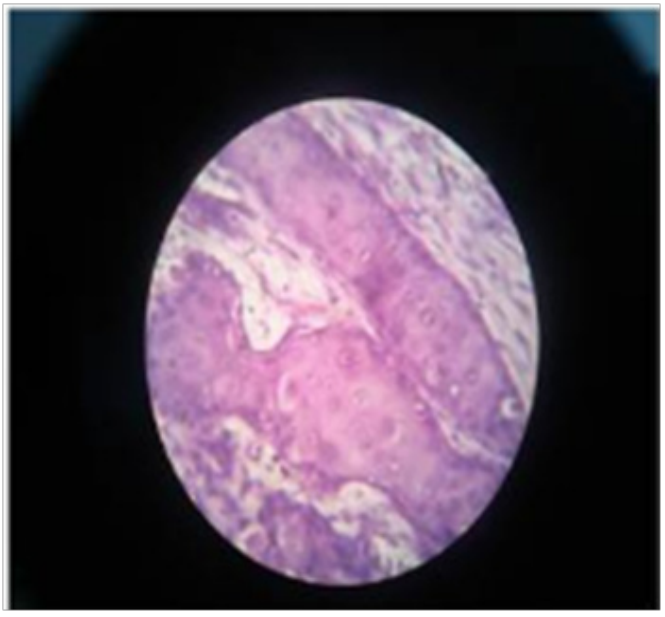

Figure 16 Granular cell tumor.

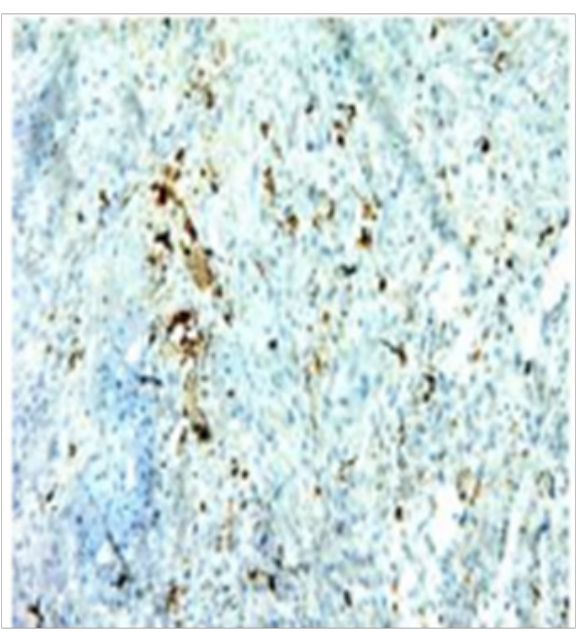

Figure 17 Showing SI00 and CYTOKERATIN positivity. 


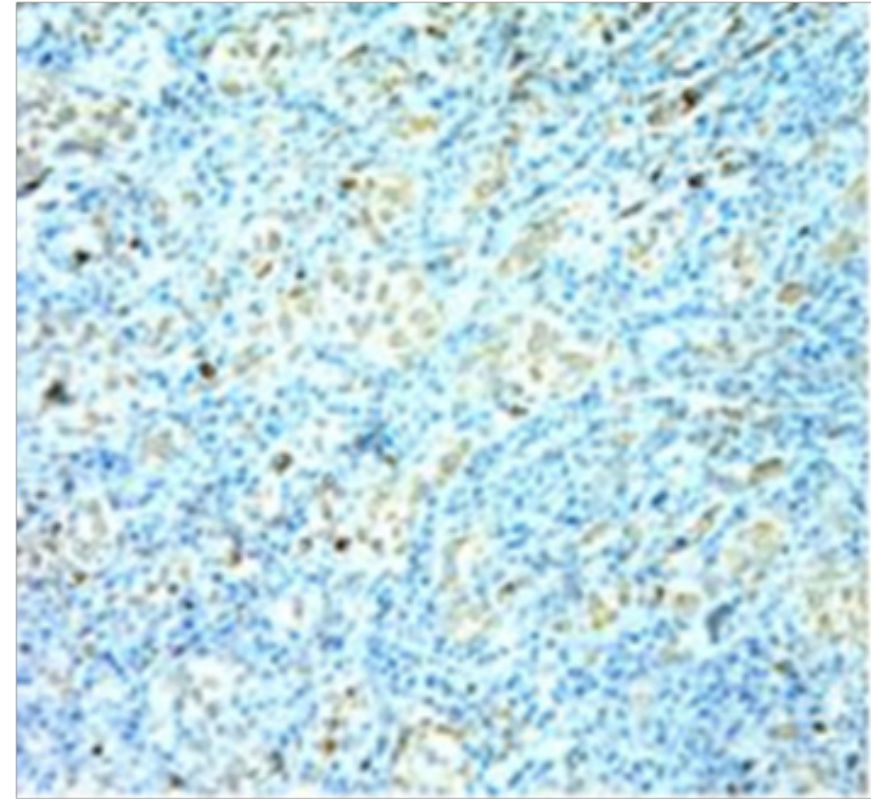

Figure 18 Showing SIOO and CYTOKERATIN positivity.

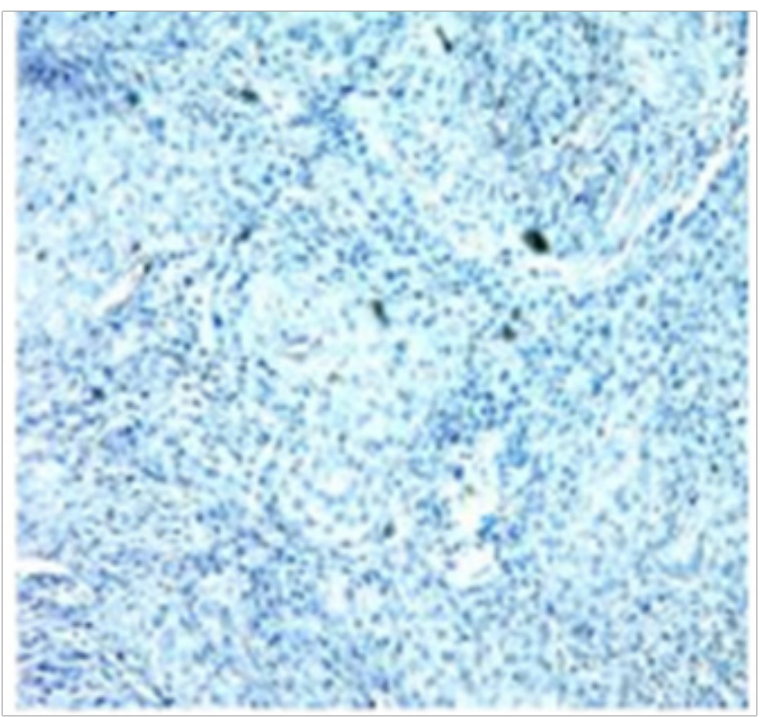

Figure 19 MYOGENIN negativity.

\section{Summary}

Majority of the soft tissue tumors can be diagnosed by their individual characteristics on routine haematoxylin and eosin sections under light microscopy. Hence the light microscopy still remains as the basic method for the diagnosis of soft tissue tumors in majority of the institutes. Newer techniques such as cytogenetic, Immunocytochemistry and electron microscopic study being widely used diagnostic tools to solve the difficult cases of soft tissue tumors. Although these methods are more reliable, their high cost is the major drawback. Immunocytochemical methods also have a limitation of significant overlapping in their findings among different soft tissue tumors and no single marker alone can reliably be used to substantiate the presumptive diagnosis. In the "Histomorphology study of soft tissue tumors" total 5895 cases were reviewed, out of which
794 cases were soft tissue origin. Majority of which were benign with the ratio of 12:1 Histological most common benign tumor among females was leiomyoma followed by haemangioma and lipoma and common malignant were Rhabdomyosarcoma and synovial sarcoma. While in male common benign was Haemangioma followed by lipoma and common malignant was Fibrosarcoma followed by Rhabdomyosarcoma.

\section{Acknowledgements}

None.

\section{Conflict of interest}

The author declares no conflict of interest.

\section{References}

1. Kransdorf MJ. Benign soft-tissue tumours in a large referral population: distribution of specific diagnoses by age, sex, and location. AJR Am J Roentgenol. 1995;164(2):395-402.

2. Kransdorf MJ. Malignant soft tissue tumours in a large referral population: distribution of specific diagnosis by age, sex and location. AJR Am J Roentgenol. 1995;164(1):129-134.

3. Hassawi BA, Suliman AY, Hasan IS. Soft tissue tumours-histopathological study of 93cases. Ann Coll Med Mosul. 2010;36(1-2):92-98.

4. Eriksson M, Hardell L, Adami HO. Exposure to dioxins as a risk factor for soft tissue sarcoma: a population-based case-control study. J Natl Cancer Inst. 1990;82(6):1785-1786.

5. Eriksson M, Hardell L, Berg NO, et al. Soft-tissue sarcomas and exposure to chemical substances: a case-referent study. Br J Ind Med. 1981;38:2733.

6. Karlsson P, Holmberg E, Samuelsson A, et al. Soft tissue sarcoma after treatment for breast cancer-a Swedish population-based study. Radiother Oncol. 1996;34(1):2068-2075.

7. McClain KL, Leach CT, Jenson HB, et al. Association of epstein-barr virus with leiomyosarcomas in children with AIDS. $N$ Engl $J$ Med. 1995;332(1):12-18.

8. Weiss RA, Whitby D, Talbot S, et al. Human herpesvirus type 8 and Kaposi's sarcoma. J Natl Cancer Inst Monogr. 1998; 1998:51-54.

9. Hisada M, Garber JE, Fung CY, et al. Multiple primary cancers in families with Li-Fraumeni syndrome. J Natl Cancer Inst. 1998;90(8):606-611.

10. Hauben EI, Arends J, Vandenbroucke JP, et al. Multiple primary malignancies in osteosarcoma patients. Incidence and predictive value of osteosarcoma subtype for cancer syndromes related with osteosarcoma. Eur J Hum Genet. 2003;11:611-618.

11. Draper GJ, Sanders BM, Kingston JE. Second primary neoplasms in patients with retinoblastoma. Br J Cancer. 1986;53:661-671.

12. Launonen V, Vierimaa O, Kiuru M, et al. Inherited susceptibility to uterine leiomyomas and renal cell cancer. Proc Natl Acad Sci USA. 2001;98(6):3387-3392.

13. Myhre, Jenson O. Histopathological staging in soft tissue tumours in relation to in 261 surgically treated patients. Acta Pathol, Microbial Immunol Seana (A). 91:145.

14. Stout AP, Lattes R. Tumours of soft tissues. In atlas of tumour pathology series 2 fascicle 1. Washington DC, USA: AFIP; 1967.

15. Angervall L, Kindblom LG, Rydholm A, et al. The diagnosis and prognosis of soft tissue tumours semin diagn. Semin Diagn Pathol. 1986;(4)3:240. 
16. Enzinger FM, Weiss SW. Soft tissue tumors St. louis. The CV mosby co; 1988

17. Lawrence W Jr, Donegan WL, Natarajan N, et al. Adult soft tissue sarcomas a pattern of case survey of American college of surgeons. Ann Sur. 1987;205(4):349-359.

18. Costa J, Wesley RA, Glatstein E, et al. The grading of soft tissue sarcomas Results of a clinicopathological correlation in a series of 163 cases. Cancer. 1984;53(3):530

19. Trojani M, Contesso G, Coindre JM, et al. Soft tissue sarcomas of adults, study of pathological prognostic variables \& definition of histopathological grading system. Int J Cancer. 1984;333:37-42.

20. Tsujimoto M, Aozasa K, Ueda T, et al. Multivariate analysis for histological prognostic factors in soft tissue sarcomas. Cancer. 1988;62(5):994-998.

21. Oberman HA, Sullenger G. Neurogenous tumours of head and neck Cancer. 1967;20:1992-2001.

22. Don O Gore Surg Gyn \& Obst. Augus.

23. Evans. Histological appearances of Tumors. Am J Surg Pathol. 1980;197.

24. Iwasaki H, Enjoji M. Infantile \& adult fibrosarcoma of soft tissues. Acta pathol Jpn. 1979;29(3):377-388.

25. Weiner JM, Hidayat AA. Juvenile fibrosarcoma of the orbit and eyelid. A study of five cases. Arch Ophthalmol. 1983;101(2):253-259.

26. Gutirez. G. Dermatofibrosarcoma Protruberans - review of 30 Cases. Int JDermat US; 1984

27. Cagle LA, Mirra JM, Storm FK, et al. Histologic features relating to prognosis in synovial sarcoma. Cancer. 1987;59(10):1810-1814.

28. Leslie A. Histologic features relating to prognosis in synovial Sarcoma Cancer. 1987;59(10):1810-1814.

29. Pritchard DJ, Soule EH, Taylor WF, et al. clinicopathological \& statistical study of 199 tumours of soft tissues. Cancer. 1974;33(3):888-897.

30. Hashimoto H, Tsuneyoshi M, Enjoji M. Malignant smooth muscle tumours of retroperitoneum and mesentry. A clinicopathological analysis of 44 cases. J Surg Oncol. 1985;28(3):177-186.

31. Wile AG, Evans HL, Romsdahl MM. Leiomyosarcoma of soft tissue- A clinic pathologic study. Cancer. 1981;48(4):1022-1032.

32. Rosai J. Carcinoma of the pancreas simulating giant cell tumor of bone: electron microscopic evidence of its acinar origin. Cancer. 1968;22(2):333344 .

33. Cubilla AL, Fitzgerald PJ. Tumors of the exocrine pancreas. In: Atlas of Tumor Pathology, fascicle 19. Armed Forces institute of Pathology, Washington, USA: Dc; 1984. p. 162-220.

34. Berendt RC, Shnitka TK, Wiens E, et al. The osteoclast-type giant cell tumor of the pancreas. Arch Pathol Lab Med. 1987;111(1):43-48.

35. Kay S, Harrison JM. Unusual pleomorphic carcinoma of the pancreas featuring production of osteoid. Cancer. 1969;23(5):1158-1162.

36. Robinson L, Damjanov, Brezina P. Multinucleated giant cell neoplasm of the pancreas: Light and electron microscopic features. Arch Pathol LabMed. 1977;101(11):590-593.

37. Trepta RW, Mathur B, Lagin S, et al. Giant cell tumor ("osteoclastoma") of the pancreas: A tumor of epithelial origin. Cance. 1981;48(9):42022-2028.

38. Posen JA. Giant cell tumor of the pancreas of the osteoclastic type associated with a mucous secreting cystadenocarcinoma. Hum Pachol. 1981;12(10):944-947.
39. Jeffrey, Crow J, Elkin BW. Osteoclast-type giant cell tumor of the pancreas. J Clin Pathol. 1983;36(10):1165-1170.

40. Jalloh SS. Giant cell tumor (osteoclastoma) of the pancreas: An epithelial tumor probably of pancreatic acinar origin. J Clin Paiho. 1983;36(10):1171-1175

41. Manci EA, Gardner LL, Pollock WJ, et al. Osteoclastic giant cell tumor of the pancreas: Aspiration cytology, light microscopy, and ultrastructure with review of the literature. Diagn Cytopathol. 1985;1(2):105-110.

42. Mentzel T, Katenkamp D. Sclerosing, pseudovascular rhabdomyosarcoma in adults. Clinicopathological and immunohistochemical analysis of three cases. Virchows Arch. 2000;436:305-311.

43. Folpe AL, McKenney JK, Bridge JA, et al. Sclerosing rhabdomyosarcoma in adults: report of four cases of a hyalinizing, matrix-rich variant of rhabdomyosarcoma that may be confused with osteosarcoma, chondrosarcoma, or angiosarcoma. Am J Surg Pathol. 2002;26(9):11751183

44. Chiles MC, Parham DM, Qualman SJ, et al. Sclerosing rhabdomyosarcomas in children and adolescents: a clinicopathologic review of 13 cases from the intergroup Rhabdomyosarcoma study group and children's oncology group. Pediatr Dev Pathol. 2004;7:583-594.

45. Croes R, Debiec-Rychter M, Cokelaere K, et al. Adult sclerosing rhabdomyosarcoma: cytogenetic link with embryonal rhabdomyosarcoma. Virchows Arch. 2005;446(1):64-67.

46. Kuhnen C1, Herter P, Leuschner I, et al. Sclerosing pseudovascular rhabdomyosarcoma-immunohistochemical, ultrastructural, and genetic findings indicating a distinct subtype of rhabdomyosarcoma. Virchows Arch. 2006;449(5):572-578.

47. Wang J, Tu X, Sheng W. Sclerosing rhabdomyosarcoma: a clinicopathologic and immunohistochemical study of five cases. Am J Clin Pathol. 2008;129(3):410-415

48. Robinson JC, Richardson MS, Neville BW, et al. Sclerosing Rhabdomyosarcoma: report of a case arising in the head and neck of an adult and review of the literature. Head Neck Pathol.1994;7(2):193-202.

49. Weiss SW, Goldblum JR. Enzinger and Weiss's soft tissue tumors. 5th ed. London: Rhabdomyosarcoma Philadelphia; 2008. p. 595-631.

50. Anders Rydholm. A review of 278 cases of malignant fibrous histiocytoma Cancer. 1986;57:232.

51. Lopes RI, Leite KR, Lopes RN. Paratesticular leiomyosarcoma treated by enucleation. Int Braz J Urol. 2006;32(1):66-67.

52. Dangle P, Basavaraj DR, Bhattarai S, et al. Leiomyosarcoma of the spermatic cord: case report and literature review. Can Urol Assoc J. 2007;1(1):55-58

53. Fisher C, Goldblum JR, Epstein JI, et al. Leiomyosarcoma of the paratesticular region: a clinicopathologic study. Am J Surg Pathol. 2001;25(9):1143-1149.

54. Kamal SA, Othman EO. Granular cell tumour of the larynx. J Laryngol Otol. 1998;112(1):83-85.

55. Leache Pueyo JJ, Alfaro García J, Cardiel García MJ, et al. Granular cell tumor of the larynx. An Otorrinolaringol Ibero Am. 1997;24(1):49-56.

56. Lazar RH, Younis RT, Kluka EA, et al. Granular cell tumor of the larynx: report of two pediatric cases. Ear Nose Throat J. 1992;71(9):440-443.

57. Garín L, Barona R, Basterra J, et al. Granular cell tumor (Abrikossoff's tumor).A review and our experience. An Otorrinolaringol Ibero Am. 1992;19(3):249-264. 